RENATA Moura GonÇALVES

ESPAÇO FÍSICO E ESPAÇO VIRTUAL NA LIBERDADE DE EXPRESSÃo

\author{
DisSERTAÇÃo DE MESTRAdO \\ Orientadora Prof. a Associada Elza Antônia PEREIRA Cunha BoiteuX
}

FACULDADE DE DiREITO DA UnIVERSIDADE DE SÃo PAULO

SÃo PAULO

2013 
RENATA MOURA GONÇALVES

\title{
ESPAÇO FísICO E ESPAÇO VIRTUAL NA LIBERDADE DE EXPRESSÃo
}

\author{
DisSERTAÇÃo DE MESTRAdO \\ Orientadora Prof. ${ }^{a}$ Associada Elza Antônia Pereira Cunha Boiteux
}

\begin{abstract}
TRABALHO APRESENTAdo PARA OBTENÇÃO Do TÍtulo DE Mestre No CURSo DE PósGRADUAÇÃo StRICTO SENSU DA FACULDAdE DE DiREITo DA UniVERsidAdE DE SÃO PAULO
\end{abstract}

FACULDADE DE DiREITO DA UNIVERSIDAdE DE SÃo PAULO

SÃo PAULO 


\section{INTRODUÇÃO}

A proposta deste trabalho acadêmico consiste em discutir os principais aspectos em torno do exercício da liberdade de expressão no espaço virtual, tendo por objetivo investigar a possibilidade de superação de eventuais restrições impostas no espaço físico ao exercício desta liberdade. Deste modo, o tema de pesquisa para a Dissertação de Mestrado volta-se para o contexto atual da sociedade informacional. Pretende-se, destarte, tratar das recentes ferramentas oferecidas pelos avanços tecnológicos para a realização da liberdade, especificamente, da liberdade de expressão.

Para a consecução deste escopo, objetiva-se, primeiramente, esclarecer alguns aspectos relacionados à liberdade de expressão, o que inclui algumas particularidades referentes à nomenclatura, à classificação, ao conteúdo, ao significado, aos fundamentos e às teorias desta liberdade. Deste modo, é possível afastar as imprecisões terminológicas comumente verificadas no tratamento da matéria. Ademais, visa-se a fornecer um panorama da liberdade de expressão exercida precipuamente no espaço físico e por meio dos veículos de comunicação de massa para, posteriormente, apontar as diferenças do exercício desta liberdade no espaço virtual.

Ademais, com o exame da sociedade informacional, procurar-se-á identificar os atributos do atual contexto que incidem no exercício da liberdade de expressão. Assim, será possível oferecer um visão acerca da liberdade de expressão na sociedade informacional.

Nesta esteira, cumpre, ainda, tecer algumas considerações introdutórias sobre características do contexto da sociedade informacional, as quais, muito embora não possam ser consideradas totalmente inéditas, trazem especificidades que justificam o interesse pela pesquisa nesta seara.

Em primeiro lugar, observa-se que a noção de uma sociedade de risco não é exclusiva dos tempos atuais. Desde remotos registros, a ideia de risco erige-se como marca distintiva da história da humanidade. ${ }^{1}$ Sem se limitar ao plano da vivência no mundo da

\footnotetext{
${ }^{1}$ Neste sentido: "O que distingue os milhares de anos de história do que consideramos os tempos modernos? A resposta transcende em muito o progresso da ciência, da tecnologia, do capitalismo e da democracia. $O$ passado remoto foi repleto de cientistas brilhantes, de matemáticos, de inventores, de tecnólogos e de filósofos políticos. Centenas de anos antes do nascimento de Cristo, os céus haviam sido mapeados, a grande
} 
natureza, os seres humanos tornam-se os próprios criadores de outros objetos do conhecimento que acabam por compor uma dimensão cultural ${ }^{2}$ legada a cada geração subsequente. ${ }^{3}$ Esta característica inerente aos seres humanos torna-os os únicos entes os quais, nas palavras de Miguel REALE, são enquanto devem ser. ${ }^{4}$ Destarte, as pessoas apresentam não apenas uma dimensão no mundo do ser, sede dos objetos naturais e das relações causais necessárias; mas também uma dimensão no mundo do dever ser, onde se apresentam os valores. A cultura resultaria, portanto, da integração destas duas dimensões. ${ }^{5}$

Transitando entre estes dois mundos, os seres humanos buscam retirar da natureza o máximo que ela tem a oferecer, objetivando sempre transpor os obstáculos por ela impostos. ${ }^{6}$ Todavia, a despeito desta preocupação marcadamente técnica, não se pode descurar das considerações éticas quanto aos fins. ${ }^{7}$

biblioteca de Alexandria fora construída e a geometria de Euclides era ensinada. A demanda por inovações tecnológicas para fins bélicos era tão insaciável quanto atualmente. Carvão, óleo, ferro e cobre estiveram a serviço dos seres humanos por milênios, e as viagens e comunicações marcaram os primórdios da civilização conhecida. A idéia revolucionária que define a fronteira entre os tempos modernos e o passado é o domínio do risco: a noção de que o futuro é mais do que um capricho dos deuses e de que homens e mulheres não são passivos diante da natureza.(...) Ao mostrar ao mundo como compreender o risco, medi-lo e avaliar suas conseqüencias, eles [pensadores] converteram o ato de correr riscos em um dos principais catalisadores que impelem a sociedade ocidental moderna. (...) A transformação nas atitudes em relação à administração do risco desencadeada por suas realizações canalizou a paixão humana pelos jogos e apostas para o crescimento econômico, a melhoria da qualidade de vida e o progresso tecnológico. (...) A palavra risco deriva do italiano antigo risicare, que significa ousar. Neste sentido, o risco é uma opção, e não um destino. É das ações que ousamos tomar, que dependem o nosso grau de liberdade de opção, que a história do risco trata (grifo nosso)." (P. L. BERNSTEIN, Against the gods, trad. port de Ivo Korylowski, Desafio aos deuses - a fascinante história do risco, $14^{\mathrm{a}}$ ed., Rio de Janeiro, Elsevier, 1997, pp.01-08.). Ainda, sobre sociedade de risco, U. BECK, Risikogesellschaft - auf dem Weg in eine andere Moderne, 1986, trad. ingl. de Mark Ritter, Risk society - towards a new modernity, Londres, Sage, 2007.

2 Conforme afirma Miguel REAlE: "Vimos que a cultura, consoante explanação de Simmel, pode ser considerada o patrimônio de espiritualidade constituído pela espécie humana através do tempo. Na cultura, contém-se, portanto, tudo aquilo que o homem adicionou e continua adicionando à natureza, aperfeiçoandoas às suas tendências fundamentais.” ( Filosofia do direito, $20^{\mathrm{a}}$ ed., São Paulo, Saraiva, 2002, p.240.)

${ }^{3}$ Para Hannah ARENDT: "Este mundo, contudo, não é idêntico à terra ou à natureza como espaço limitado para o movimento dos homens e condição geral da vida orgânica. Antes, tem a ver com o artefato humano, com o produto de mãos humanas, com os negócios realizados entre os que, juntos, habitam o mundo feito pelo homem." (The human condition, trad. port. de Roberto Raposo, A condição humana, 10 ${ }^{\mathrm{a}}$ ed., Rio de Janeiro, Forense Universitária, 2008, p.62.)

${ }^{4}$ Consoante Miguel Reale: "Já dissemos que o homem é o único ser capaz de valores. Poderíamos dizer, também, que o ser do homem é o seu dever ser.” (Filosofia do direito, 20ª ed., São Paulo, Saraiva, 2002, p.211.)

${ }^{5}$ Cf. M. Reale, Filosofia do direito, 20a ed., São Paulo, Saraiva, 2002, p.211.

6 Para Tercio Sampaio FERRAZ JUNIOR: "a tecnologia moderna deixa de nascer de uma verdade contemplada pela ciência, surgindo antes, como diz Heidegger, de uma exigência imposta pelo homem à natureza para esta entregar-lhe a sua energia acumulada." (Introdução ao estudo do direito - técnica, decisão, dominação, $3^{\mathrm{a}}$ ed., São Paulo, Atlas, 2001, p.86.)

${ }^{7}$ Nesta esteira, Elza Antonia Pereira Cunha BoITEUX observa que: "Para compreender o mundo que o cerca, o ser humano precisa da ciência e da integração solidária com outras áreas do saber. A técnica, por que não incorpora a dimensão dos valores, pode servir à qualquer interesse (à vida ou à morte). (Educação e valores 
Na chamada sociedade informacional, ${ }^{8}$ o esforço humano em extrapolar as barreiras naturais para a realização plena de sua inventividade alcançou a superação da equação espaço-temporal. ${ }^{9}$ O espaço e o tempo, os quais antes eram entendidos como a estrutura em que a realidade está contida, de modo que nada de real pudesse ser concebido fora de seus limites condicionantes, ${ }^{10}$ sofreram sensíveis alterações em seus significados com o advento da Internet,${ }^{11}{ }^{12}$ a qual já integra o cotidiano de dois bilhões de pessoas. ${ }^{13}$

Assim, ainda que se argumente que a exclusão digital torna a Internet um fenômeno desconhecido para a maioria dos seres humanos que vivem alheios aos avanços informáticos, ${ }^{14}$ não se pode negar que a rede mundial de computadores já atinge aproximadamente um terço da população do planeta, o que exige respostas para os seus

ambientais, in Elza Antonia Pereira Cunha BoITEUX (coord.), Direitos humanos - estudos em homenagem ao Professor Fábio Konder Comparato, Salvador, JusPodivm, 2010, p. 44.)

${ }^{8}$ Cf. M. CASTELls, The rise of Network society, 1942, trad. port. de Roneide Venancio Majer, A sociedade em rede, vol. I, $7^{\mathrm{a}}$ ed., São Paulo, Paz e Terra, 2003, p.565.

${ }^{9}$ Cf. F. H. PODESTÁ, Direito à intimidade em ambiente da Internet, in LUCCA, Newton de - SIMÃO FILHO, Adalberto, Direito \& Internet - aspectos jurídicos relevantes, Bauru, Edipro, 2001, pp. 155-176.

${ }^{10}$ Com efeito: "O espaço e o tempo são a estrutura em que toda a realidade está contida. Não podemos conceber qualquer coisa real exceto sob as condições do espaço e do tempo. Nada no mundo, segundo Heráclito, pode exceder suas medidas - e estas são limitações espaciais e temporais." (E. CASSIRER, Na essay on man - na introduction to a philosophy of human culture, trad. port. de Tomás Rosa Bueno, Ensaio sobre o homem - introdução a uma filosofia da cultura humana, São Paulo, Martins Fontes, 1994, p.73.)

${ }^{11}$ Acerca da alteração na noção de tempo: “O YouTube (www.youtube.com) é a comunidade de vídeos mais popular da Internet. (...) A cada minuto, diz Hurley [um dos criadores do YouTube], usuários do site enviam o equivalente a 24 horas de conteúdo para o site, ou 34.560 horas por dia em vídeos, que são armazenados em centros de dados espalhados pelo mundo." (Um dia de 34.560 horas, in Folha de São Paulo - Caderno Ilustrada, 30/08/09, p.E2.)

${ }^{12}$ Cumpre ressalvar que outros meios de comunicação igualmente alteraram a equação espaço-temporal. Neste sentido, lembra André LEMOS que: "Os media podem ser considerados como instrumentos de simulação, formas técnicas de alterar o espaço-tempo. Será no século XIX que diversas inovações mediáticas aparecerão, a começar em 1837 com o telégrafo elétrico, o telefone em 1875, o telégrafo por ondas hertzianas em 1900 e um ano antes, o cinema. Em 1964, o primeiro satélite de comunicação, o Telstar, revoluciona nossa visão de mundo e instaura um espaço de informação cobrindo todas as áreas do planeta." (Cibercultura - tecnologia e vida social na cultura contemporânea, $5^{\mathrm{a}}$ ed., Porto Alegre, Sulina, 2010, p. 68.)

${ }^{13}$ Cf. Número de usuários de Internet no mundo alcança 2 bilhões, in Globo.com, 26/01/2011, Disponível em <http://g1.globo.com/tecnologia/noticia/2011/01/numero-de-usuarios-de-internet-no-mundo-alcanca-os2-bilhoes.html>. Acesso em: 09 de jan. 2013. Este número de usuários já havia sido previsto, conforme aponta Manuel CASTELls: "O uso da Internet como sistema de comunicação e de forma de organização explodiu nos últimos anos do segundo milênio. No final de 1995, o primeiro ano de uso disseminado da world wide web, havia cerca de 16 milhões de usuários de redes de comunicação por computadores no mundo. No início de 2001, eles eram mais de 400 milhões; previsões confiáveis apontam que haverão cerca de um bilhão de usuários em 2005, e é possível que estejamos nos aproximando da marca de dois bilhões por volta de 2010, mesmo levando em conta uma desaceleração da difusão da Internet quando ela penetrar no mundo da pobreza e do atraso tecnológico." (The Internet galaxy - reflections on the Internet, business and society, 2001, trad. port. de Maria Luiza X. de A. Borges, A galáxia da Internet - reflexões sobre a Internet, os negócios e a sociedade, Rio de Janeiro, Jorge Zahar, 2003, p.08.)

${ }^{14}$ Sobre a exclusão digital: "A centralidade da Internet em muitas áreas da atividade social, econômica e política equivale à marginalidade para aqueles que não têm acesso a ela, ou têm apenas um acesso limitado, bem como para os que são incapazes de usá-la eficazmente.” (Manuel CASTELLS, The Internet galaxy reflections on the Internet, business and society, 2001, trad. port. de Maria Luiza X. de A. Borges, A galáxia da Internet - reflexões sobre a Internet, os negócios e a sociedade, Rio de Janeiro, Jorge Zahar, 2003, p.203.) 
problemas peculiares. ${ }^{15}$ Estes já não podem ser satisfatoriamente resolvidos pelos mecanismos tradicionais desenvolvidos para atender a um cenário totalmente diverso.

O contexto da Internet apresenta necessidades próprias e, como tal, enseja um estudo e uma análise detalhados, a fim de que sejam alcançadas as respostas adequadas para os problemas suscitados a partir deste novo âmbito, no qual se inserem as transformações tecnológicas em relação às quais, embora situadas no domínio da técnica, em que se pretende criar condições para ação, não se pode deixar de questionar sobre as finalidades, tendo em vista a consecução dos valores sustentados em uma determinada sociedade. ${ }^{16}$

As constantes notícias veiculadas nos mais diversos meios de comunicação sobre problemas envolvendo a Internet reforçam a ideia de que se trata de uma realidade específica para a qual os métodos tradicionais, à luz de antigos paradigmas, deixaram de oferecer operacionabilidade. Assim, mais uma vez, os seres humanos precisam colocar em prática seu gênio criador, a fim de solucionar os problemas decorrentes das novas tecnologias por eles mesmos criadas. A dificuldade maior ocorre, pois, muitas vezes, as consequências desencadeadas com a aplicação prática de uma nova tecnologia sequer foram imaginadas pelos seus próprios criadores. ${ }^{17}$

Neste sentido, a Internet, a qual foi concebida em consonância com os ideais de cooperação e de liberdade de informação, voltados para a inovação, ${ }^{18}$ com o propósito de viabilizar a continuidade da comunicação a despeito de eventuais danificações

\footnotetext{
${ }^{15}$ Neste sentido, Pierre LÉVY, traçando um paralelo com o telefone, observa que: "O telefone gerou $e$ continua a gerar verdadeiras fortunas para as companhias de telecomunicação. Isso não altera o fato de que as redes de telefonia permitem uma comunicação planetária e interativa. Ainda que apenas um quarto da humanidade tenha acesso ao telefone, isso não constitui um argumento 'contra' ele. Por isso, não vejo por que a exploração econômica da Internet ou o fato de que atualmente nem todos têm acesso a ela constituiriam, por si mesmos, uma condenação da cibercultura ou nos impediriam de pensá-la de qualquer forma que não crítica." (Cyberculture, trad. port. de Carlos Irineu da Costa, Cibercultura, $3^{\mathrm{a}}$ ed., São Paulo, 34, 2010, pp.12-13.)

${ }_{16}$ Com efeito, conforme afirma Fábio Konder COMPARATO: "Técnica e ética complementam-se, necessariamente, para impulsionar os povos e as civilizações a se unirem. A tecnologia, divorciada da ética, conduz à inevitável fratura da humanidade." (Ética - direito, moral e religião no mundo moderno, São Paulo, Companhia das Letras, 2006, p. 435.)

${ }^{17}$ Cf. J.M.S.SÁNCHEZ, La expansión del derecho penal - aspectos de la política criminal em las sociedades postindustriales, trad. port. de Luiz Otavio de Oliveira Rocha, A expansão do direito penal - aspectos da política criminal nas sociedades pós-industriais, São Paulo, Revista dos Tribunais, 2002, pp. 29-41.

${ }^{18} \mathrm{Cf}$. M. CASTELLS, The Internet galaxy - reflections on the Internet, business and society, 2001, trad. port. de Maria Luiza X. de A. Borges, A galáxia da Internet - reflexões sobre a Internet, os negócios e a sociedade, Rio de Janeiro, Jorge Zahar, 2003, p.13.
} 
sofridas em decorrência de ataques bélicos, ${ }^{19}$ não foi cogitada, em seus primórdios, como uma ferramenta para cercear a liberdade individual. No entanto, como a Internet consiste em um meio, o qual pode ser direcionado para diferentes finalidades, ela pode ser utilizada tanto para o fomento da liberdade humana, quanto para a dominação do indivíduo, ao servir aos propósitos, por exemplo, de invasão da privacidade de seus usuários. De fato, estes sequer têm o conhecimento de quem os está vigiando. ${ }^{20}$

Todavia, a própria maneira pela qual a Internet foi criada, como um sistema em rede, não favorece a possibilidade de um controle centralizado efetivo. Ela surgiu exatamente para não sofrer nenhum controle. Deste modo, se, por um lado, a organização em rede adéqua-se à sociedade informacional, por ser flexível às alterações vertiginosas da atualidade; por outro lado, ela não apresenta uma centralização administrativa que permita um domínio sobre todo o seu sistema. Neste ponto, localiza-se a raiz dos problemas acerca do controle da Internet. ${ }^{21}$

Além disto, não se pode deixar de mencionar que a valorização do indivíduo, em contraposição, não apenas ao Estado, mas à coletividade como um todo, desfavorece as tentativas de implantação de medidas que signifiquem uma restrição à liberdade individual. A força da Internet repousa, em grande medida, na ausência de restrições impostas para satisfazer as vontades e os interesses individuais. Assim, a própria mentalidade dominante opõe resistência às alterações no sentido de regulamentar a Internet. $^{22}{ }^{23}$

\footnotetext{
19 "O projeto Arpanet da agência de projetos avançados (Arpa) do departamento de defesa norte-americano confiou, em 1969, à Rand Corporation a elaboração de um sistema de telecomunicações que garantisse que um ataque russo não interrompesse a corrente de comando dos Estados Unidos." (L. M. PAESANI, Direito e Internet - liberdade de informação, privacidade e responsabilidade civil, $3^{\mathrm{a}}$ ed., São Paulo, Atlas, 2006, p.25.)

${ }^{20}$ Neste sentido, cumpre lembrar o modelo do Panopticon, de Bentham; e o Grande Irmão, de George Orwell: "Mas hoje, em decorrência da aumentada capacidade de 'ver' os comportamentos dos cidadãos, através da informação pública de centros cada vez mais aperfeiçoados e eficazes, muito além daquele que Orwell poderia prever (o intervalo entre a ficção científica e a ciência é, devido ao progresso vertiginoso dos nossos conhecimentos, cada vez mais curto), o modelo do Panopticon torna-se ameaçadoramente atual." (N. BoBBio, Teoria geral da política - a filosofia política e a lição dos clássicos, Rio de Janeiro, Campus, 2000, pp.401.)

${ }^{21}$ Cf. M. CASTELLS, The Internet galaxy - reflections on the Internet, business and society, 2001, trad. port. de Maria Luiza X. de A. Borges, A galáxia da Internet - reflexões sobre a Internet, os negócios e a sociedade, Rio de Janeiro, Jorge Zahar, 2003, pp. 7-12.

${ }^{22}$ Neste sentido, interessa citar as ações civis propostas pela American Library Association (Civil Action n. ${ }^{\circ}$ 96-1458) em face do Departamento de Justiça dos Estados Unidos; e pela American Civil Liberties Union (Civil Action n..$^{\circ}$ 96-963) em face de Janet Reno, Attorney General of the United States. No caso, buscava-se contestar a constitucionalidade do Communications Deceny Act (CDA), o qual constitui o título V do Ato das Telecomunicações de 1996. As organizações e os indivíduos envolvidos na ação estão associados com a
} 
A constatação dos novos contornos da sociedade informacional, os quais ensejam a mudança do paradigma piramidal para o paradigma em rede, e dos problemas peculiares impostos pela Internet aos aplicadores e aos intérpretes do Direito suscitou o interesse para uma pesquisa sobre esta nova conjuntura, de modo a apresentar-se como a justificativa para escolha do tema do presente trabalho.

A revolução conduzida pelos avanços da informática, observada com maior vigor na Internet, inspira cautela, em vista da amplitude e da velocidade de universalização de questões antes limitadas pelas dimensões de espaço e de tempo nas quais ocorreu a ação. Esta rapidez torna precária qualquer tentativa de garantir a segurança e a previsibilidade das relações humanas ocorridas no âmbito da rede mundial de computadores. $^{24}$

A maior vagarosidade do legislador para acompanhar as evoluções dos fenômenos sociais é há muito tempo conhecida. O Direito vê-se, por conseguinte, constantemente ocupado pela tarefa de renovação. ${ }^{25}$ Com o advento da sociedade

indústria de comunicação que publica material na Internet. Em resumo, alegam que duas disposições do CDA voltadas para a comunicação na Internet infringem, entre outros, os direitos protegidos pela Primeira Emenda. Com efeito, os dispositivos contêm expressões muito vagas, tais como "indecente" ou "ofensiva para menores", o que significaria uma afronta à liberdade de expressão. De acordo com o primeiro dispositivo questionado, qualquer pessoa que, em comunicação inter-estatal ou estrangeira, por algum meio de comunicação faz, cria, solicita e inicia a transmissão de qualquer comentário, pedido, sugestão, proposta, imagem ou outra comunicação que é obscena ou indecente, sabendo que o receptor é menor de 18 anos, deve ser criminalmente preso. Já o segundo, por sua vez, torna crime usar serviço interativo de computador para enviar a menor de 18 anos conteúdo obsceno ou indecente. Ora, como estas matérias já eram criminalizadas, não haveria necessidade para constar novamente no CDA. As partes concordam que, para destacar as questões legais suscitadas no caso, é necessário ter uma compreensão clara do crescimento exponencial deste meio de comunicação mundial que é a Internet. Ora, a Internet apresenta facetas únicas concernentes à aplicação da jurisprudência da Primeira Emenda e dos requisitos do devido processo para este novo meio de comunicação. A história e a tecnologia da Internet não estão em discussão no caso, mas as partes, de comum acordo, entenderam por bem analisar a natureza do ciberespaço, bem como o desenvolvimento deste e a criação da Internet. Cf. The United States District Court for the Eastern District of Pennsylvania, Civil Action n. ${ }^{\circ}$ 96-963, Civil Action n. ${ }^{\circ}$ 96-1458, 11/06/1996, Disponível em <http://www.law.duke.edu/boylesite/aclureno.htm>. Acesso em: 09 jan. 2013.

${ }_{23}$ Conforme ressalta Manuel CASTELLS: "No dia 12 de junho de 1996, um tribunal federal dos EUA na Pensilvânia declarou o Communications Decency Act de 1995 inconstitucional, afirmando: 'Assim como a força da Internet é o caso, assim a força da liberdade depende do caos e da cacofonia da expressão livre que a Primeira Emenda protege' (...) Por causa da dificuldade de levar os EUA a tomar o partido da regulação da comunicação por computador, e dada a natureza global da rede, a tentativa direta pelo Estado de controlar a Internet por meio tradicionais de censura e repressão parece ter fracassado." (The Internet galaxy - reflections on the Internet, business and society, 2001, trad. port. de Maria Luiza X. de A. Borges, A galáxia da Internet - reflexões sobre a Internet, os negócios e a sociedade, Rio de Janeiro, Jorge Zahar, 2003, p.140.)

${ }^{24}$ Cf. F. H. PODESTÁ, Direito à intimidade em ambiente da Internet, in LUCCA, Newton de - SIMÃO FILHO, Adalberto, Direito \& Internet - aspectos jurídicos relevantes, Bauru, Edipro, 2001, pp. 155-176.

${ }^{25}$ Neste passo: "O legislador tem sempre passo trôpego. Caminha com vagar. Bem mais lentamente que os fatos sociais. Que evoluem e reivindicam normas e providências. Mas que vão avante, valores novos ou 
informacional, todavia, a discrepância entre a velocidade das alterações sociais e a presteza da resposta dada pelo legislador a esta nova realidade delineada acirrou-se ainda mais.

O cenário da rede mundial de computadores, ao colocar em contato as pessoas independentemente da localização física e do fuso horário, favoreceu o surgimento de situações antes inusitadas, de modo a exigir uma resposta a despeito da inexistência de legislação específica que se aplique à nova realidade do contexto informático. Esta deve tomar como base o paradigma da rede, o qual, em comparação com o tradicional modelo piramidal, apresenta-se como mais adequado para esta situação.

De fato, na sociedade atual, vigora a máxima segundo a qual informação é poder. Ao adotar esta premissa, o desenho institucional da sociedade voltou-se para viabilizar a propagação e o acúmulo de dados, o que ocorreu de maneira mais aperfeiçoada por meio da Internet. O veloz desenvolvimento tecnológico gerou uma dependência social em relação à informação, com reflexos para as relações de sociabilidade humana. ${ }^{26}$

Assim, a Internet passa a desempenhar um papel de grande relevância na dinâmica das relações humanas que ultrapassam as fronteiras nacionais, constituindo, por conseguinte, um poderoso instrumento insuscetível a um rigoroso controle centralizado. ${ }^{27}$

Tendo em vista que a Internet consiste em um instrumento tecnológico que pode ser orientado para a consecução de diversas finalidades, cumpre ressalvar que a rede

desprotegidos que surgem, a reclamar tutela. A tarefa de renovação é ininterrupta." (Cf. P. J. DA COSTA JR., $O$ direito de estar só - tutela penal da intimidade, São Paulo, Revista dos Tribunais, 1970, p.07)

${ }^{26}$ Nesta esteira: "Vivemos, atualmente, em uma sociedade em que, segunda a máxima, a informação é poder, vale dizer, quanto mais informação mais poder. Fala-se, então, de uma sociedade da informação, tendo em vista o grau da sociabilidade humana e o nível de desenvolvimento tecnológico das comunicações hoje existentes, fatores que facilitam substancialmente o intercambio de informações. Isso resulta que a informação, considerada como meio de formação de ideias, concepções ou simples elementos de difusão de notícias, acontecimentos etc., possua uma importância crucial na sociedade atual.” (M. C. PEREIRA, Direito à intimidade na Internet, Curitiba, Juruá, 2006, p.141.)

${ }^{27}$ De fato, a despeito do desenvolvimento de tecnologias de controle, ainda é possível afirmar que a Internet não apresenta um rigoroso controle centralizado. Deste modo, afirma Manuel CASTELLS: "Uma variedade de tecnologias de controle emergiu dos interesses entrelaçados do comércio e dos governos. Há tecnologias de identificação, de vigilância e de investigação." No entanto, mais adiante, reconhece o autor que: "Tecnologias de controle podem ser neutralizadas por tecnologias de liberdade. E há uma abundância delas, muitas vezes produzidas e comercializadas por empresas que encontram um novo nicho de mercado; em outros casos, são inventadas por combatentes resolutos da liberdade, dispostos a aceitar o desafio." (The Internet galaxy - reflections on the Internet, business and society, 2001, trad. port. de Maria Luiza X. de A. Borges, A galáxia da Internet - reflexões sobre a Internet, os negócios e a sociedade, Rio de Janeiro, Jorge Zahar, 2003, pp. 141 e 150.) 
mundial de computadores, em si mesma considerada, não é o poder, mas pode ser utilizada tanto para obter o poder, quanto para resistir ao poder. $^{28}$

A atual conjuntura da interligação de dados em uma rede global cuja principal característica é a espontaneidade das ações de indivíduos situados em diferentes localidades, sem a existência de um controle centralizado que imponha padrões objetivos de conduta para todos ao mesmo tempo, coloca em pauta o tema da liberdade do indivíduo. A liberdade no contexto da rede mundial de computadores se faz por meio da comunicação. Deste modo, não se deve de maneira restrita falar de liberdade à comunicação, mas sim de liberdade por meio da comunicação. ${ }^{29}$

O ideal do Iluminismo, segundo o qual a liberdade individual deveria ser afirmada como valor preponderante para a consecução da dignidade da pessoa humana, deve ser alterado diante das novas circunstâncias verificadas no contexto de um mundo interligado pela Internet. Tercio Sampaio FERRAZ JUNIOR propõe que a dignidade humana deva ser centrada no viver em livre comunicação com o outro. O indivíduo, entendido como ente comunicativo, não deve ser encarado, de modo estanque, ora como agente - eu ora como paciente - outro. Cada um constitui uma unidade agente/paciente na rede de comunicação. ${ }^{30}$

Uma pessoa que estivesse fora dessa rede comunicacional, isoladamente, seria nula. A liberdade na rede somente poderá ser plenamente realizada, se a própria rede, enquanto meio de comunicação, for livre. ${ }^{31}$

Nesta esteira, para Tercio Sampaio FERRAZ JUNIOR, os benefícios auferidos com a liberdade e a espontaneidade predominantes no campo da comunicação em rede não podem ser invocados como justificativa para os abusos do agente privado. A liberdade de expressão e a proteção da intimidade apresentam um valor imensurável para a coletividade.

\footnotetext{
${ }^{28}$ Sobre o poder: "Como assinala Friedrich (1937, 12), nem coisas nem ideias 'tomadas isoladamente são poder, mas podem tornar-se instrumentos nas mãos de quem procura o poder. Para convertê-las em poder, quem procura o poder deve encontrar seres humanos que valorizem suficientemente as coisas para, em troca, obedecer às suas ordens (...)” (A. KAPLAN; H. LASSWEL, Power and society - a framework for political inquiry, Trad. Port. de Maria Lucy Gurgel Valente de Seixas Corrêa. Poder e sociedade. Brasília: UnB, 1979, p.112.)

${ }^{29}$ Cf. T. S. FERRAZ JUNIOR, A Liberdade como Autonomia recíproca de acesso à informação, in Estudos de Filosofia do Direito, São Paulo, Atlas, 2002, pp.133 - 139.

${ }^{30} \mathrm{Cf}$. A Liberdade como Autonomia recíproca de acesso à informação, in Estudos de Filosofia do Direito, São Paulo, Atlas, 2002, pp.133 - 139.

${ }^{31}$ Cf. T. S. FERraz JunIOR, A Liberdade como Autonomia recíproca de acesso à informação, in Estudos de Filosofia do Direito, São Paulo, Atlas, 2002, pp.133 - 139.
} 
O indivíduo, egoisticamente, não deve pensar que a liberdade na rede pertence-lhe tal como um objeto de propriedade privada. Deve-se, pois, admitir a proteção da liberdade limitada à responsabilização do agente. A proteção da liberdade na Internet deve ser vista como uma proteção da comunicação em si e não meramente do agente privado que se comunica por meio da rede. $^{32}$

A liberdade afirmada após as revoluções liberais consiste na liberdade em sua acepção moderna. Esta almeja proteger o indivíduo contra as imposições arbitrárias do corpo social e viabilizar o desenvolvimento da atividade econômica livre da interferência estatal. $\mathrm{O}$ conceito de liberdade moderna, que surgiu para responder às necessidades de um momento histórico específico das revoluções liberais, não é adequado para solucionar, por si só, os conflitos relacionados à liberdade na sociedade informacional. ${ }^{33}$

A Internet, como estrutura reticular, não apresenta um centro de poder. Ela não pertence a instituições, governos ou organizações internacionais. ${ }^{34}$ Há somente um consenso quanto à linguagem e aos protocolos adotados. ${ }^{35} \mathrm{~A}$ falta de órgãos gestores da Internet torna-a uma exceção na seara tradicional dos meios de telecomunicações. ${ }^{36}$ Estas

${ }^{32}$ Cf. A Liberdade como Autonomia recíproca de acesso à informação, in Estudos de Filosofia do Direito, São Paulo, Atlas, 2002, pp.133 - 139.

${ }^{33}$ Neste passo, Manuel CASTELLS destaca a necessidade de repensar o papel do governo em relação à liberdade na Internet. Com efeito, afirma o autor: "Grande parte desta análise, como a ideologia da maior parte dos movimentos dos primeiros usuários da Internet, funda-se no pressuposto implícito de que os governos não são aliados da liberdade. Entretanto, sabemos a partir da história que a democracia institucional, não a ideologia libertária, foi o principal baluarte contra a tirania. Assim, por que não confiar aos governos, pelo menos aos democráticos, a regulação dos usos corretos da Internet?" No entanto, para que isto ocorra, os governos não podem temer a Internet como um instrumento de controle, de acesso à informação, de participação e de tomada de decisão de baixo para cima por parte dos cidadãos. Assim: “ $A$ menos que os governos parem de temer seu povo, e por conseguinte a Internet, a sociedade recorrerá mais uma vez às barricadas para defender a liberdade, o que sinalizará impressionante continuidade histórica." (The Internet galaxy - reflections on the Internet, business and society, 2001, trad. port. de Maria Luiza X. de A. Borges, A galáxia da Internet - reflexões sobre a Internet, os negócios e a sociedade, Rio de Janeiro, Jorge Zahar, 2003, pp. 151-152.)

34 De fato, afirma L. G. Grandinetti Castanho de CARVAlHo: "Mas é induvidoso que a Internet veio revolucionar o processo informativo, contribuindo para a democratização da informação, pois a rede não é de ninguém; ninguém a tutela; ninguém a gerencia. É ela um patrimônio cultural da sociedade cosmopolita. É uma verdadeira instituição que nasceu espontaneamente e com abrangência realmente universal." (Liberdade de informação e direito difuso à informação verdadeira, 2a ed., São Paulo, Renovar, 2003, pp.201-202.)

${ }^{5}$ Com efeito: “A Internet não pertence a ninguém, não é financiada por instituições, governos ou organizações internacionais, e também não é um serviço comercial.” (L.M.PAESANI, Direito e Internet liberdade de informação, privacidade e responsabilidade civil, $3^{\mathrm{a}} \mathrm{ed}$., São Paulo, Atlas, 2006, p.36.)

${ }^{36}$ Impõe-se aqui a ressalva de que a Internet dispõe, atualmente, de regras em relação ao standard e ao endereço eletrônico, sem as quais não seria possível a comunicação. Assim, há quem considere que, apenas em momentos iniciais, os usuários dispuseram de maior liberdade na Internet em comparação com outras redes de comunicação. Neste sentido, cumpre mencionar, por exemplo, a ICANN (Internet Corporation for Assigned Names and Numbers), a qual se situa no âmbito de regulação da Internet. 
peculiaridades relacionam-se, como visto, à gênese da Internet como meio ilimitado de distribuição de conteúdos. ${ }^{37}$

Nesta esteira, a despeito de se verificar a configuração de uma ilicitude na seara da Internet, as autoridades jurisdicionais encontram-se atadas à legislação de suas respectivas ordens jurídicas, inaptas para extrapolar a dimensão territorial e para alcançar o ambiente da rede mundial de computadores. ${ }^{38}$ Assim, na maioria das vezes, o fenômeno legal, enquanto circunscrito a um território nacional, não apresenta a abrangência necessária para regular este novo campo de comunicação que constitui a Internet. ${ }^{39}$

Muito embora os avanços da Internet tenham significado um aumento da transparência na circulação de informações, o que beneficia a liberdade em sua acepção democrática, fornecendo meios adequados para que o cidadão acesse a esfera pública, como bem observa Lilian Minardi PAESANI, este espaço livre da Internet pode perverter-se e culminar no aprisionamento do indivíduo em situações de conflito para as quais não se vislumbra um adequado equacionamento entre as legislações de diferentes ordens jurídicas envolvidas. $^{40}$

O problema de controle que se impõe no meio informático não é inédito, visto que se assemelha à questão suscitada no que concerne a moedas e a ativos financeiros, os quais circulam sem se sujeitaram a nenhum Banco Central, apenas orientando-se pela regulação específica de paraísos fiscais. Ademais, a ineficácia do controle também se faz presente na tentativa de coibir, por exemplo, a lavagem de dinheiro no âmbito internacional. ${ }^{41}$

\footnotetext{
${ }^{37}$ Cf. L. M. PAESANI, Direito e Internet - liberdade de informação, privacidade e responsabilidade civil,

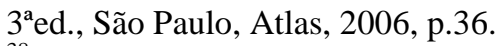

${ }^{38}$ Sobre o assunto: "Em contrapartida, as autoridades judiciárias estão presas às normas e instituições do Estado e, portanto, a uma Nação e a um território limitado. Configura-se o conflito e a dificuldade de aplicar controles judiciais na rede e surge o problema da aplicação das regras." (L.M.PAESANI, Direito e Internet - liberdade de informação, privacidade e responsabilidade civil, $3^{\mathrm{a}}$ ed., São Paulo, Atlas, 2006, p.36.)

${ }^{39}$ Cf. I. G. S. MARTINS, e R. V. G. S. MARTINS, Privacidade na comunicação eletrônica, in Direito e Internet - relações jurídicas na sociedade informatizada, Marco Aurélio Greco, e Ives Granda da Silva Martins (orgs.), São Paulo, Revista dos Tribunais, 2001, p.41.

${ }^{40}$ Cf. L. M.PAESANI, Direito e Internet - liberdade de informação, privacidade e responsabilidade civil,

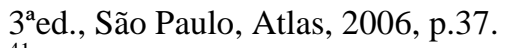

${ }^{41}$ Cf. I.G.S. MARTINS, e R.V.G.S. MARTINS, Privacidade na comunicação eletrônica, in Direito e Internet relações jurídicas na sociedade informatizada, Marco Aurélio Greco, e Ives Granda da Silva Martins (orgs.), São Paulo, Revista dos Tribunais, 2001, p.42.
} 
Particularmente, em relação à Internet, duas variáveis explicam a maior dificuldade de controle. A primeira consiste na ampla possibilidade de que a divulgação de conteúdo parta de qualquer localidade, inclusive fora do alcance da regulamentação jurídica. A segunda refere-se à dificuldade de identificar o emissor da informação. ${ }^{42}$

Diante deste atual contexto, caracterizado, em especial, pelas inovações decorrentes da Internet, é cabível o questionamento acerca do tema da liberdade de expressão à luz das novas perspectivas oferecidas pelos avanços tecnológicos da sociedade informacional.

Assim, no capítulo 1, serão tecidas considerações sobre a liberdade de expressão, de modo a fornecer um arcabouço teórico para o desenvolvimento da ideia central do trabalho acerca do exercício da liberdade de expressão no espaço virtual. No capítulo 2, parte-se para o exame da sociedade informacional, bem como da noção do paradigma da rede, da relação entre o direito e o espaço virtual e, enfim, da concepção de liberdade na rede. Em seguida, no capítulo 3, tem-se como objetivo a análise da liberdade de expressão na sociedade informacional, com ênfase para as principais mudanças impostas à liberdade de expressão neste novo contexto. Por fim, no capítulo 4, segue-se o estudo do exercício da liberdade de expressão no espaço virtual, com enfoque no surgimento de uma nova esfera pública mundial e na liberação do polo de emissão permitida com o advento da Internet. Além disto, nesta oportunidade, abordam-se alguns casos práticos acerca das novas perspectivas, oferecidas pelo advento do espaço virtual, para a superação das restrições impostas no espaço físico à consecução da liberdade de expressão.

\footnotetext{
${ }^{42}$ Neste sentido: "Em outras palavras, no mundo da comunicação eletrônica, o 'ativo financeiro' é a informação e esta migra com velocidade surpreendente, assalta os informatizados e pode restar sem paternidade, a partir da genialidade dos que a manipulam ou do refúgio em países em que a legislação seja flexível ou pouco severa." (I.G.S. MARTINS, e R.V.G.S. MARTINS, Privacidade na comunicação eletrônica, in Direito e Internet - relações jurídicas na sociedade informatizada, Marco Aurélio Greco, e Ives Granda da Silva Martins (orgs.), São Paulo, Revista dos Tribunais, 2001, p.43.)
} 


\section{CONCLUSÃo}

Ao tratar do tema da liberdade de pensamento, é recorrente a distinção entre o aspecto interno e o aspecto externo da liberdade. Assim, enquanto permanecesse como um estado de consciência, de crença ou de convicção íntima, o pensamento estaria fora do alcance do Direito. Por este motivo, entendia-se haver uma ampla liberdade de pensamento, de modo a não ser necessária uma preocupação com a sua tutela jurídica.

No entanto, a despeito deste entendimento inicial de que a liberdade de pensamento poderia ser livremente exercida no âmbito interno do sujeito, sem qualquer interferência de limites ou de controles externos, reconheceu-se a relação existente entre o aspecto interno e o aspecto externo da liberdade, a qual daria ensejo a considerações acerca de sua proteção pelo Direito.

Com efeito, deve-se admitir que a liberdade de pensamento do indivíduo, em seu âmbito interno, exige condições externas para o seu desenvolvimento. Ademais, tem-se como uma das principais características do pensamento a tendência a se externar, de modo que o indivíduo apenas realizará em plenitude a sua liberdade de pensamento caso consiga expressá-lo adequadamente aos demais, seja por meio de seus próprios comportamentos, adotados em consonância com os seus pensamentos, seja por meio de qualquer forma de exteriorização.

Neste sentido, a partir da livre expressão dos pensamentos individuais, forma-se um ambiente de pluralismo de ideias que fornece as condições externas necessárias para o desenvolvimento interno da liberdade de pensamento. Por conseguinte, passa-se a falar em liberdade de expressão, a qual exige um espaço físico exterior ao sujeito para se desenvolver.

Neste contexto, a liberdade de expressão assume notável relevância, sendo muitas as teorias que visam a explicar o seu fundamento. De modo geral, é possível identificar duas diferentes correntes. A primeira destas correntes concebe a liberdade de expressão como indispensável para a plena realização do indivíduo. A ênfase repousa, portanto, na esfera privada, sendo possível identificar uma relação com a liberdade em sua acepção moderna. A segunda corrente, por sua vez, entende a liberdade de expressão como 
indispensável para a plena realização da democracia. Neste caso, a ênfase situa-se sobre a esfera pública, traçando-se uma relação com a liberdade em sua acepção antiga.

No entanto, o entendimento acerca do exercício da liberdade de expressão foi objeto de muitas transformações em face das possibilidades decorrentes das inovações tecnológicas na seara das comunicações. Desta forma, se, em um momento anterior, o exercício da liberdade de expressão ocorria, principalmente, por meio da escrita ou da fala, circunscrita a um espaço físico e a um tempo determinados, com o desenvolvimento dos meios de comunicação, alargam-se as possibilidades de exercício da liberdade de expressão.

De fato, com a invenção do telégrafo, do rádio, do telefone e do cinema, por exemplo, torna-se possível alterar a equação espaço-temporal, alcançando-se, em um curto período de tempo, distâncias mais longas. Contudo, no contexto dos meios de comunicação de massa, como a televisão, o rádio e a imprensa, novos desafios são impostos ao exercício da liberdade de expressão pelo sujeito. Ocorre que, a despeito da larga abrangência destes veículos de comunicação, o acesso a estes é limitado.

Esta situação, no entanto, sofrerá profundas alterações diante das novas tecnologias de comunicação e de informação, entre as quais merece destaque a Internet. Trata-se de uma rede mundial de computadores, a qual, por meio da linguagem digital, permite o advento do espaço virtual. Nesta nova seara de comunicação humana, os mais diversos conteúdos, entre textos, sons e imagens, são expressos em dígitos, podendo ser enviados e acessados a qualquer tempo, em qualquer local, por qualquer indivíduo conectado à Internet.

Apresenta-se, destarte, uma sociedade informacional, precipuamente eletrônica e digital. Nesta, o mundo pode ser traduzido em termos de informações, as quais são transmissíveis em dados binários por meio da rede mundial de computadores. Ademais, em virtude das rápidas alterações decorrentes da velocidade das inovações tecnológicas, do novo ritmo das comunicações, bem como da interconexão entre indivíduos de diferentes ordens jurídicas por meio da Internet, desponta a necessidade de trabalhar com o paradigma em rede. 
$\mathrm{Na}$ esteira destes pressupostos, as transformações tecnológicas da sociedade informacional alteram as condições do discurso, o que reflete no exercício da liberdade de expressão. A Internet, entendida como rede de telecomunicação com alta capacidade de difundir informações, independentemente das limitações espaço-temporais, consiste em uma variável nova que altera os termos do debate, de modo a ensejar uma revisão sobre o tema.

Observa-se a possibilidade de encontrar, no espaço virtual, a superação de eventuais limitações ao exercício da liberdade de expressão enfrentadas no espaço físico. Fala-se, portanto, em uma ampliação da liberdade de expressão no espaço virtual. Ora, nesta seara, cada indivíduo dispõe dos instrumentos necessários para fazer ecoar a sua voz ao longo de todo ponto do planeta em que seja possível conectar-se à rede mundial de computadores.

Libera-se, por conseguinte, o polo de emissão que, na lógica dos meios de comunicação de massa, se concentrava nas mãos de poucos. Com efeito, as antigas barreiras existentes entre produtores, consumidores e gestores de informação são dissipadas, de modo que a avaliação e a crítica deslocam-se dos tradicionais mediadores como o clero, o editor e o jornalista para alcançar a multidão de indivíduos interconectados por meio da rede mundial de computadores.

Ademais, no espaço virtual, os conteúdos são criados e organizados pelos próprios usuários. Rompem-se, destarte, os limites que distinguiam a figura do criador de determinado conteúdo. Ora, na livre comunicação de ideias em rede, o conhecimento é coletivamente construído e compartilhado. Forma-se uma nova esfera pública mundial e digital, que não sofre os recortes das fronteiras territoriais dos Estados.

Neste contexto, os valores de abertura, de colaboração e de comunicação de muitos para muitos assumem grande relevância. Os indivíduos organizam-se e relacionamse no espaço virtual por meio de redes sociais. Há, ainda, uma capacidade inesgotável de armazenamento de informações e de conteúdos no espaço virtual, que podem ser transmitidos e acessados de qualquer ponto.

Diante destas novas possibilidades verificadas no espaço virtual, há um reflexo positivo sobre o exercício da liberdade de expressão, em seu sentido amplo, de 
modo a abranger, além da exteriorização do pensamento pelo indivíduo, o acesso à informação e as liberdades de ação coletiva, como a liberdade de associação. Assim, no espaço virtual, superando-se as limitações das teorias que identificam um fundamento monista para a liberdade de expressão, ora localizado na autonomia do indivíduo, ora na busca pela democracia, a liberdade de expressão deve ser entendida à luz de uma nova teoria, a qual abarque o exercício da liberdade de expressão no espaço virtual em sua plenitude, com destaque para a interatividade, para a ampla participação dos indivíduos no processo de formação cultural e para a criação de novos significados a partir de antigos conceitos.

Ora, todos estes avanços para o exercício da liberdade de expressão no espaço virtual são possíveis, em grande medida, em virtude da arquitetura da rede mundial de computadores. Nesta, as mensagens são igualmente enviadas a qualquer ponto da rede, sem observar as barreiras geográficas ou as fronteiras territoriais do Estado. Além disto, a arquitetura da Internet dificulta a identificação do indivíduo que a acessa a partir de determinado nó. Estes fatores configuram desafios tanto para a proteção de outros aspectos da liberdade do indivíduo, tais como a privacidade, quanto para as pretensões governamentais de regulação do discurso perpetrado no espaço virtual.

Surgem, por conseguinte, propostas e tentativas para alterar a atual configuração do espaço virtual, como um ambiente aberto e colaborativo, a fim de aumentar a possibilidade de controle pelos Estados.

Diante deste contexto, verifica-se a necessidade de considerar todos os benefícios alcançados para o exercício da liberdade de expressão no espaço virtual, com destaque para o potencial de inovação, o acesso à informação, o aumento de transparência, a liberação do polo de emissão, a possibilidade de associação e de relação entre os indivíduos por meio de redes sociais, por exemplo, a fim de, adequadamente, defender a liberdade de expressão no espaço virtual. 


\section{BIBLIOGRAFIA}

AlEXY, Robert, Theorie der Grundrechte, trad. port. de Virgílio Afonso da Silva, Teoria dos direitos fundamentais, São Paulo, Malheiros, 2008.

Alves, José Carlos Moreira, Direito Romano, $3^{\text {a }}$ ed.,vol.I, Rio de Janeiro, Forense, 1971.

AMARAl JÚNIOR, Alberto, A solução de controvérsias na OMC e a aplicação do direito internacional, Tese (Titularidade) Faculdade de Direito da U.S.P., São Paulo, 2006.

ANDRADE, Manuel Costa, Os novos crimes contra as pessoas - a experiência da reforma penal portuguesa, 1982-1995, in Revista Brasileira de Ciências Criminais, São Paulo, v.4, n.16, out./dez. 1996.

ArEndT, Hannah, Between Past and Future, trad. port. de Mauro W. Barbosa, Entre o passado e o futuro, $2^{\text {a }}$ ed., São Paulo, Perspectiva, 1979.

ARENDT, Hannah, The human condition, trad. port. de Roberto Raposo, A condição humana, $11^{\text {a }}$ ed., Rio de Janeiro, Forense Universitária, 2010.

ARISTÓTELES, Ética a Nicômaco, trad. port. de Leonel Vallandro e Gerd Bornheim, São Paulo, Abril, 1984.

Ascensão, José de Oliveira, Direito da Internet e da sociedade da informação - estudos, Rio de Janeiro, Forense, 2002.

BALKIN, Jack M., Digital speech and democratic culture - a theory of freedom of expression for the information society, in N.Y. U. Law Review, vol. 79, 2004, pp.01-55.

BECK, Ulrich, Risikogesellschaft - auf dem Weg in eine andere Moderne, 1986, trad. ingl. de Mark Ritter, Risk society - towards a new modernity, Londres, Sage, 2007.

BERLIN, Isaiah, Dois conceitos de liberdade, in Quatro ensaios sobre a liberdade pensamento político, trad. port. de Wamberto Hudson Ferreira, Brasília, Universidade de Brasília, 1981. 
BernsteIn, Peter Lewyn, Against the gods, trad. port. de Ivo Korylowski, Desafio aos deuses - a fascinante história do risco, 14ª ed., Rio de Janeiro, Elsevier, 1997.

Binenbojm, Gustavo, Meios de comunicação de massa, pluralismo e democracia deliberativa - as liberdades de expressão e de imprensa nos Estados Unidos e no Brasil, Disponível em: 〈http://www.mundojuridico.adv.br>, Acesso em: 09 de jan. de 2013.

BÔAS FILHO, Orlando Villas, Teoria dos sistemas e o direito brasileiro, São Paulo, Saraiva, 2009.

Boввio, Norberto, Il futuro della democrazia, trad. port. de Marco Aurélio Nogueira, $O$ futuro da democracia, 9a ed., São Paulo, Paz e Terra, 2000.

BobBIo, Norberto, Il terzo assente, trad. port. de Daniela Versiani, O terceiro ausente, São Paulo, Manole, 2009.

Boвbio, Norberto, Teoria geral da política - a filosofia política e a lição dos clássicos, Rio de Janeiro, Campus, 2000.

BobBio, Norberto, Teoria do ordenamento jurídico, $10^{\mathrm{a}}$ ed., Brasília, Universidade de Brasília, 1997.

BoiteuX, Elza Antonia Pereira Cunha (coord.), Direitos humanos - estudos em homenagem ao Professor Fábio Konder Comparato, Salvador, JusPodivm, 2010.

Borteux, Elza Antonia Pereira Cunha, O princípio da solidariedade e os direitos humanos de natureza ambiental, in Revista da Faculdade de Direito da Universidade de São Paulo, 2010.

Bonavides, Paulo, Curso de direito constitucional, 25ª ed., São Paulo, Malheiros, 2010.

BURGESS, Jean, e GREEN, Joshua, YouTube - digital media and society series, trad. port. de Ricardo Giassetti, YouTube e a revolução digital - como o maior fenômeno de cultura participativa está transformando a mídia e a sociedade, São Paulo, Aleph, 2009.

CAMPos, Gérman J. Bidart, Teoría general de los derechos humanos, México, Universidad Nacional Autónoma de México, 1989. 
Carvalho, Luis Gustavo Grandinetti Castanho de, Liberdade de informação e direito difuso à informação verdadeira, $2^{\mathrm{a}}$ ed., São Paulo, Renovar, 2003.

CASTELls, Manuel, The internet galaxy - reflections on the internet, business and society, 2001, trad. port. de Maria Luiza X. de A. Borges, A galáxia da internet - reflexões sobre a internet, os negócios e a sociedade, Rio de Janeiro, Jorge Zahar, 2003.

CASTELls, Manuel, The rise of Network society, 1942, trad. port. de Roneide Venancio Majer, A sociedade em rede, vol. I, $7^{\mathrm{a}}$ ed., São Paulo, Paz e Terra, 2003.

Coloma, Aurelia Maria Romero, Derecho a la informacion y libertad de expresion especial consideracion al proceso penal, Barcelona, Bosch, 1984.

Comparato, Fábio Konder, A afirmação histórica dos direitos humanos, $2^{\mathrm{a}}$ ed., São Paulo, Saraiva, 2001.

Comparato, Fábio Konder, A democratização do poder mundial, In Juízes para democracia, n.23, v.5, 2001, pp.10-11.

Comparato, Fábio Konder, Capitalismo - civilização e poder, in Boletim de ciências econômicas, Coimbra, 2011, pp.03-58.

COMPARAto, Fábio Konder, Ética - direito, moral e religião no mundo moderno, São Paulo, Companhia das letras, 2006.

COMPARATO, Fábio Konder, Rumo à justiça, São Paulo, Saraiva, 2010.

Constant, Benjamin, De la liberte des anciens comparée a celle des modernes, 1819, trad. port. de Loura Silveira, A liberdade dos antigos comparada à dos modernos, Campinas, L\&PM, 1985.

Costa Junior, Paulo José da, O direito de estar só - tutela penal da intimidade, São Paulo, Revista dos Tribunais, 1970.

Coulanges, Numa Denis Fustel de, A cidade antiga - estudo sobre o culto, o direito e as instituições da Grécia e de Roma, São Paulo, Revista dos Tribunais, 2003. 
Cretella Júnior, José, Comentários à constituição brasileira de 1988, vol. I, $3^{\mathrm{a} e d .,}$ Rio de Janeiro, Forense Universitária.

DAHRENDORF, Ralf, O futuro da liberdade, in Sociedade e liberdade - pensamento político, trad. port. de Vamirech Chacon, Brasília, Universidade de Brasília, 1981.

Dallari, Dalmo de Abreu, Elementos de teoria geral do estado, 23 ${ }^{\mathrm{a}}$ ed., São Paulo, Saraiva, 2002.

Deleuze, Gilles, Pourparlers, trad. port. de Peter Pál Pelbart, Conversações, $2^{\mathrm{a}}$ ed., São Paulo, 34, 2010.

Deleuze, Gilles, O atual e o virtual, in Deleuze, Giles, e PARnet, Claire, Dialougues, Paris, Flammarion, 1996.

Dinamarco, Cândido Rangel, Instituições de direito processual civil, vol.I, $5^{\mathrm{a}}$ ed., São Paulo, Malheiros, 2005.

Dowbor, Ladislau, IANNI, Octavio, e ReSEnde, Paulo-Edgar A., Desafios da globalização,

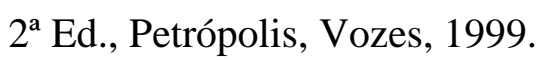

EASTERBROOK, Frank Hoover, Cyberspace and the Law of the horse, 1996, University of Chicago Law Forum, Disponível em: <https://www.law.upenn.edu/law619/f2001/week15/easterbrook.pdf> Acesso em: 19 nov. 2012.

ESSENFELDER, Renato, Comunidades falsificadas - filósofo espanhol diz que a utopia da democracia direta e igualdade na internet é mentirosa e ameaça minar as práticas de representação e participação políticas reais, in Folha de São Paulo - Caderno Mais, São Paulo, 23/08/09, p.10.

FARAlLI, Carla, A filosofia contemporânea do Direito - temas e desafios, São Paulo, Martins Fontes, 2006.

FARIAS, Cristiano Chaves de (org.), Leituras complementares de direito civil - o direito civil-constitucional em concreto, $2^{\mathrm{a}}$ ed., Salvador, JusPodivm, 2009. 
FARIAS, Edilsom, Colisão de direitos - a honra, a intimidade, a vida privada e a imagem versus a liberdade de expressão e informação, $2^{\mathrm{a}}$ ed., Porto Alegre, Sergio Antonio Fabris, 2000.

FARIAS, Edilsom, Liberdade de expressão e de comunicação - teoria e proteção constitucional, São Paulo, Revista dos Tribunais, 2004.

FERRAZ Junior, Tercio Sampaio, A Liberdade como autonomia recíproca de acesso à informação, in Estudos de Filosofia do Direito, São Paulo, Atlas, 2002, pp. 153-159.

FERRAZ JUNIOR, Tercio Sampaio, Estudos de filosofia do direito - reflexões sobre o poder, a liberdade, a justiça e o direito, $2^{\mathrm{a}}$ ed., São Paulo, Atlas, 2003.

Ferraz Junior, Tercio Sampaio, Introdução ao estudo do direito - técnica, decisão, dominação, $3^{\text {a }}$ ed., São Paulo, Atlas 2001.

FERRAZ JUNIOR, Tercio Sampaio, Liberdade de informação e privacidade ou o paradoxo da liberdade, in A. do AMARAl JúnIOR, C. PERrone-MoIsÉs (orgs.), O Cinqüentenário da Declaração Universal dos Direitos do Homem, São Paulo, Edusp, 1998, pp.385-393.

Ferraz Junior, Tercio Sampaio, Possibilidades virtuais da realidade - ontem e hoje, in A invenção do futuro - um debate sobre a pós-modernidade e a hipermodernidade, Jorge Forbes, Miguel Reale Júnior e Tercio Sampaio Ferraz Junior (orgs.), Barueri, São Paulo, Manole, 2005, pp. 95-122.

FERRAZ JUNIOR, Tercio Sampaio, Software livre - a administração pública e a comunhão do conhecimento informático, in Direito constitucional - liberdade de fumar, privacidade, Estado, direitos humanos e outros temas, Barueri, Manole, 2007, pp.260-297.

FERRAZ JUnIOR, Tercio Sampaio, A erosão dos direitos subjetivos por força do desenvolvimento técnico, São Paulo, 2011.

FERREIRA, Aluízio, Direito à informação, direito à comunicação - direitos fundamentais na Constituição brasileira, São Paulo, Celso Bastos, 1997.

Ferreira Filho, Manoel Gonçalves, Curso de direito constitucional, $31^{\mathrm{a}}$ ed., São Paulo, Saraiva. 
FISS, Owen M., A ironia da liberdade de expressão - Estado, regulação e diversidade na esfera pública, trad. port. de Gustavo Binenbojom e Caio Mario da Silva Pereira Neto, Rio de Janeiro, Renovar, 2005.

FLUSSER, Vilém, A filosofia da caixa preta - ensaios para uma futura filosofia da fotografia, São Paulo, Annablume, 2011.

FoucAult, Michel, La verité et les formes juridiques, trad. port. de Roberto Cabral de Melo Machado e Eduardo Jardim Morais, A verdade e as formas jurídicas, $3^{\mathrm{a}}$ ed., Rio de Janeiro, Nau, 2002.

FoucAult, Michel, Microfísica do poder, $18^{\mathrm{a}}$ ed., Rio de Janeiro, Graal, 1979.

GIBSON, William, Neuromancer, $4^{\mathrm{a}}$ ed., trad. port. de Fabio Fernandes, São Paulo, Aleph, 2008.

GoldSMITH, Jack L., e WU, Tim, Who controls the internet - illusions of a borderless world, Nova York, Oxford University, 2008.

GonZALEZ, Santiago Sanchez, La libertad de expresión, Madri, Marcial Pons, 1992.

Greco, Marco Aurélio, e MArtins, Ives Gandra da Silva (coord.), Direito e Internet relações jurídicas na sociedade informatizada, São Paulo, Revista dos Tribunais, 2001.

GRINOVER, Ada Pellegrini, O crime organizado no sistema italiano, in Revista brasileira de ciências criminais, vol. 03, n. 12, São Paulo, out./dez. 1995.

GÜNTHER, Klaus, World citizens between freedom and security, in Constellations, vol.12, n.03, 2005, pp. 379-391.

HAYEK, Friedrich August von, Die Verfassung der Freiheit,1899, trad. port. de Anna Maria Capovilla, e José Ítalo Stelle, Os fundamentos da liberdade, Brasília, Unb, 1983.

HobBes, Thomas, Leviatã ou matéria, forma e poder de um Estado eclesiástico e civil, trad. port. de João Paulo Monteiro, e Maria Beatriz Nizza da Silva, São Paulo, Abril Cultural, 1983. 
ISRAEL, Jean-Jacques, Droit des Libertés Fondamentales, trad. port. de Carlos Souza, Direito das liberdades fundamentais, São Paulo, Manole, 2005.

KANT, Immanuel, A paz perpétua e outros opúsculos, trad. port. de Artur Mourão, Rio de Janeiro, 70, 1990.

KANT, Immanuel, Grundlegung zur Metaphysik der Sitten, trad. port. de Paulo Quintela, Fundamentação da metafísica dos costumes, Rio de Janeiro, 70, 1991.

KAPlan, Abraham; LASSwel, Harold, Power and society - a framework for political inquiry, trad. Port. de Maria Lucy Gurgel Valente de Seixas Corrêa, Poder e sociedade, Brasília, UnB, 1979.

Kelsen, Hans, Reine Rechtslehre, trad. port. de J. B. Machado, Teoria pura do direito, $6^{\mathrm{a}}$ ed., São Paulo, Martins Fontes, 2000.

LAFER, Celso, A reconstrução dos direitos humanos - um diálogo com o pensamento de Hannah Arendt, São Paulo, Companhia das Letras, 2006.

LAfER, Celso, Direito e Poder na reflexão de Miguel Reale in Miguel Reale na Unb, Brasília, Unb, 1981.

LAFER, Celso, Ensaios sobre a liberdade, São Paulo, Perspectiva, 1980.

LAFER, Celso, Filosofia do direito e princípios gerais - considerações sobre a pergunta o que é a Filosofia do Direito?, in O que é a Filosofia do Direito?, Alaôr Caffé Alves (Org.), Barueri, Manole, 2004.

LAFER, Celso, Paradoxos e possibilidades - estudos sobre a ordem mundial e sobre a política exterior do Brasil num sistema internacional, Rio de Janeiro, Nova Fronteira, 1982.

LEIB, Volker, Verrechtlichung im Internet - ICANN und die globale Regulierung des Domain Name System mit Recht und Macht, in Verrechtlichung - Baustein für Global Governance?, B. ZANGL, e M.ZüRN (org.), Bonn, 2004, p.02, Disponível em: <www.volker-leib.de>. Acesso em: 20 out. 2012. 
LEMOS, André, e LÉVY, Pierre, O futuro da internet - em direção a uma ciberdemocracia planetária, São Paulo, Paulus, 2010.

LEMOS, André, Cibercultura - tecnologia e vida social na cultura contemporânea, $5^{\mathrm{a}}$ ed., Porto Alegre, Sulina, 2010.

LESSIG, Lawrence, Code - version 2.0, Nova York, Basic Books, 2006.

LESSIG, Lawrence, The future of ideas - the fate of the commons in a connected world, Nova York, Random House, 2001.

LESSIG, Lawrence, The law of the horse - what cyberlaw might teach, in Harvard Law Review, vol. 113, 1999, pp.501-546.

LÉvy, Pierre, Cyberculture, trad. port. de Carlos Irineu da Costa, Cibercultura, $3^{\mathrm{a}}$ ed., São Paulo, 34, 2010.

LÉVY, Pierre, Cyberdemocratie, trad. port. de Alexandre Emílio, Ciberdemocracia, Porto Alegre, Instituto Piaget, 2002.

LÉVY, Pierre, Les Technologies de l'intelligence, trad. port. de Carlos Irineu da Costa, As tecnologias da inteligência - o futuro do pensamento na era da informática, $2^{\mathrm{a}}$ ed., Rio de Janeiro, 34, 2010.

LÉVy, Pierre, Qu'est-ce que le virtuel, trad. port. de Paulo Neves, O que é o virtual, São Paulo, 34, 1996.

Lima, José Aloísio Nunes de, Teorias da comunicação - um panorama crítico e comparativo, Maceió, UFAL, 2011.

LOCKE, John, The second treatise of government, trad. port. de Jacy Monteiro, Segundo tratado sobre o governo, São Paulo, Instituto brasileiro de difusão cultural, 1983.

LOPES, VerA MARIA DE OlIVEIRA NusDeO, O direito à informação e as concessões de rádio e televisão, São Paulo, Revista dos Tribunais, 1997.

LÓPEZ, Modesto Saavedra, La libertad de expresión en el estado de derecho - entre la utopia y la realidad, Barcelona, Ariel, 1987. 
LORES, Raul Juste, YouQuê? - um dos dez mais acessados na China, site censura temas sensíveis ao governo e paga para usar vídeos da TV estatal, in Folha de São Paulo Caderno Ilustrada, São Paulo, 20/08/09, p.E4.

Losano, Mario Giuseppe, Luño, Antonio Enrique Pérez, e Mateus, Maria Fernanda Guerreo, Libertad informática y leyes de proteccion de datos personales, Madrid, Centro de estúdios constitucionales, 1989.

Losano, Mario Giuseppe, Modelos teóricos, inclusive na prática: da pirâmide à rede novos paradigmas nas relações entre direitos nacionais e normativos supraestatais, in Revista do instituto dos advogados do estado de São Paulo, 2005, vol.8, n.16.

Losano, Mario Giuseppe, Lições de Informática Jurídica, São Paulo, Resenha Tributária, 1974.

LosAno, Mario Giuseppe, Os grandes sistemas jurídicos - introdução aos sistemas jurídicos europeus e extraeuropeus, São Paulo, Martins Fontes, 2007.

LuCCA, Newton de, e SiMÃo FILHo, Adalberto (coords.), Direito \& internet - aspectos jurídicos relevantes, $2^{\mathrm{a}}$ ed., São Paulo, Quatier Latin, 2005.

LuÑo, Antonio-Enrique Pérez, Las libertades en la era de Internet, in El derecho en redestudios en homenaje al profesor Mario G. Losano, Fco. Javier Ansuátegui Roig et alii, Madri, Dykinson, 2006.

MAIEROVITCH, Wálter Fanganiello, Gomorra - Saviano visita Jerusalém e o presidente de Israel, in Terra Magazine, 26/02/2009, Disponível em: <http://maierovitch.blog.terra.com.br/2009/02/26/gomorra-Saviano-visita-jerusalem-e-opresidente-de-israel/>. Acesso em: 09 jan 2013.

MARQues, Garcia, MARTins, Lourenço, Direito da informática, Coimbra, Almedina, 2000.

MARTino, Antonio Anselmo, e PAGLIERINI, Paola, Internet governance - legal issues, in eGovernance and public communication for na inclusive society, Disponível em: <http://www.antonioanselmomartino.it/dmdocuments/ig.pdf $>$. Acesso em: 09 jan. 2013. 
Martino, Luís Mauro Sá, Teoria da comunicação - ideias, conceitos e métodos, $3^{\mathrm{a}}$ ed., Rio de Janeiro, Vozes, 2012.

Martins, Ives Granda da Silva, Pereira Junior, Antonio Jorge (coords.), Direito à privacidade, São Paulo, Centro de Extensão Universitária, 2005.

Martins, Ives Granda da Silva e Martins, Rogério Vidal Granda da Silva, Privacidade na comunicação eletrônica, in Direito e Internet - relações jurídicas na sociedade informatizada, Marco Aurélio Greco, e Ives Granda da Silva Martins (orgs.), São Paulo, Revista dos Tribunais, 2001.

MARX, Karl, Liberdade de imprensa, trad. port. de Claudia Schilling e José Fonseca, Porto Alegre, L\&PM, 2010.

Mattelart, Armand, Historie de la société de l'information, trad. port. de Nocolás Nyimi Campanário, História da sociedade da informação, $2^{\mathrm{a}}$ ed, São Paulo, Loyola, 2006.

Mattelart, Armand, e Mattelart, Michèle, Histoire des théories de la communication, trad. port. de Luiz Paulo Rouanet, História das teorias da comunicação, $15^{\mathrm{a}}$ ed., São Paulo, Loyola, 2012.

Medauar, Odete, $O$ direito administrativo em evolução, $2^{\mathrm{a}}$ ed., São Paulo, Revista dos Tribunais, 2003.

MeIKLEJOHN, Alexander, The first amendment is an absolute, in The Supreme Court Review, 1961, pp.245-266.

Mello, Celso Antônio Bandeira de, Curso de direito administrativo, 25 ed., São Paulo, Malheiros.

Mora, Miguel, Enquanto a morte não chega, in Folha de São Paulo - Caderno Mais!, 26/04/2009, São Paulo, p. 04.

Moraes, Alexandre de, Direito constitucional, 28ª ed., São Paulo, Atlas, 2012.

MorAes, Alexandre de, Direitos humanos fundamentais - teoria geral, comentários aos arts. $1^{\circ}$ a $5^{\circ}$ da Constituição da República Federativa do Brasil, doutrina e jurisprudência, $5^{\text {a }}$ ed., São Paulo, Atlas, 2003. 
NeJIM, Rodrigo, Navegação precisa de limites, in Folha de São Paulo - Caderno de informática, São Paulo, 15/07/09, p. F4.

ORGANIZAÇÃO DAS NAÇÕES UnIDAS (ONU), COMISSÃO DE DiREITOS HuMANOS, Report of the Special Rapporteur on the promotion and protection of the right to freedom of opinion and expression, 16 nov. 2011, Disponível em: <http://www2.ohchr.org/english/bodies/hrcouncil/docs/17session/A.HRC.17.27_en.pdf> Acesso em 09 jan. 2013.

PAeSANI, Lilian Minardi, Direito e internet - liberdade de informação, privacidade e responsabilidade civil, $3^{\mathrm{a}}$ ed., São Paulo, Atlas, 2006.

PAeSANI, Lilian Minardi, Direito de informática - comercialização e desenvolvimento internacional de software, $5^{\text {a }}$ ed., São Paulo, Atlas, 2007.

Pellanda, Nize Maria Campos, e Pellanda, Eduardo Campos (orgs.), Ciberespaço - um hipertexto com Pierre Lévy, Porto Alegre, Artes e Ofícios, 2000.

PEREIRA, Marcelo Cardoso, Direito à intimidade na internet, Curitiba, Juruá, 2006.

Plascencia, David Ramírez, Conflicto de leyes y censura en internet - el caso Yahoo!, in Comunicación y Sociedad, nueva época, n. o 8, jul-dez, 2007.

Podestá, Fábio Henrique, Direito à intimidade em ambiente da internet, in LuCCA, Newton de - SIMÃo FILHO, Adalberto, Direito \& Internet - aspectos jurídicos relevantes, Bauru, Edipro, 2001.

PolanyI, Karl, The great transformation, trad. port. de Fanny Wrobel, A grande transformação - as origens de nossa época, $2^{\mathrm{a}}$ ed., Rio de Janeiro, Elsevier, 2000.

PORTO, Pedro Rui da Fontoura, Direitos fundamentais sociais - considerações acerca da legitimidade política e processual do Ministério Público e do sistema de justiça para sua tutela, Porto Alegre, Livraria do Advogado, 2006.

RADBRUCH, Gustav, Filosofia do direito, trad. port. de L. Cabral de Moncada, $4^{\mathrm{a}}$ ed., vol. II, Coimbra, Arménio Amado, 1961. 
ReAle, Miguel, Estudos de filosofia e ciência do direito, São Paulo, Saraiva, 1978.

REALE, Miguel, Filosofia do direito, 20ed., São Paulo, Saraiva, 2002.

REALE, Miguel, Fontes e modelos do direito: para um novo paradigma hermenêutico, São Paulo, Saraiva, 1994.

Reale, Miguel, $O$ Estado democrático de direito e o conflito das ideologias, $2^{\mathrm{a}}$ ed., São Paulo, Saraiva, 1999.

REALE, Miguel, Pluralismo e liberdade, São Paulo, Saraiva, 1963.

REALE, Miguel, Teoria do direito e do Estado, 5a ed., São Paulo, Saraiva, 2000.

RIBEIRO, Milton, Liberdade religiosa - uma proposta para debate, São Paulo, Mackenzie, 2002.

RIFKIN, Jeremy, The age of access, trad. port. de Maria Lucia G. L. Rosa, A era do acesso - a transição de mercados convencionais para networks e o nascimento de uma nova economia, São Paulo, Makron Books, 2001.

Rivero, Jean e Moutouh, Hugues, Les libertes publiques, trad. port. de Maria Ermantina de Almeida Prado Galvão, Liberdades públicas, São Paulo, Martins Fontes, 2006.

Rosenau, James N., The Drama of Human Rights in a turbulent, globalized world, in BRYSK Alison (ed.), Globalization and Human Rights, Berkeley, University of California, 2002.

SÁNCHEZ, Jesús-Maria Silva, La expansión del derecho penal - aspectos de la política criminal en las sociedades postindustriales, trad. port. de Luiz Otavio de Oliveira Rocha, A expansão do direito penal - aspectos da política criminal nas sociedades pós-industriais, São Paulo, Revista dos Tribunais, 2002.

SANTAELlA, Lucia, e LEMOS, Renata, Redes sociais digitais - a cognição conectiva do Twitter, São Paulo, Paulus, 2010. 
Santos, Milton, A Aceleração Contemporânea - Tempo-Mundo e Espaço-Mundo, in Dowbor, Ladislau; IAnNI, Octavio; Resende, Paulo-Edgar A. (orgs.), Desafios da Globalização, 2aed., Petrópolis, Vozes, 1999.

SAVIANO, Roberto, Gomorra, trad. port. de Elaine Niccolai, Gomorra - a história real de um jornalista infiltrado na violenta máfia napolitana, $5^{\mathrm{a}}$ ed., Rio de Janeiro, Bertrand Brasil, 2009.

SAVIANO, Roberto, entrevista concedida por Roberto Saviano, O homem blindado - autor mergulhou nos 'infernos literários' para entender sua situação e revela que entra em contato com seus leitores apenas pelo Facebook, in Folha de São Paulo - Caderno Mais!, 26/04/09, pp.05-06, Disponível em: <http://www1.folha.uol.com.br/fsp/mais/fs2604200907.htm >. Acesso em: 09 jan. 2013.

ShECAIRA, Sérgio Salomão, e Corrêa Junior, Alceu, Teoria da pena - finalidades, direito positivo, jurisprudência e outros estudos de ciência criminal, São Paulo, Revista dos Tribunais, 2002.

SILva, José Afonso da, Curso de direito constitucional positivo, $21^{\mathrm{a}}$ ed., São Paulo, Malheiros, 2002.

SIlva, José Afonso da, Comentário contextual à constituição, $4^{\mathrm{a}}$ ed., São Paulo, Malheiros, 2006.

SILVA, Virgílio Afonso da, Direitos fundamentais - conteúdo essencial, restrições e eficácia, São Paulo, Malheiros, 2009.

SEITENFus, Ricardo, Manual das organizações internacionais, $3^{\mathrm{a}}$ ed., Porto Alegre, Livraria do Advogado, 2003.

SCHNEIER, Bruce, There is no privacy on internet, trad. port. de Fabiano Fleury de Souza Campos, Não há privacidade na internet, in Folha de São Paulo - Caderno de informática, São Paulo, 15/07/09, p. F5.

SunsteIn, Cass Robert, Democracy and the problem of free speech, Nova York, Free Press, 1995. 
TEUBNER, Günther, The anonymous matrix - human rights violations by private transnational actors, in Modern Law Review, vol.69, 2006, pp.327-346.

TEUBNER, Günther, Societal constitutionalism - alternatives to State-centered constitutional theory, in Storrs Lectures, Yale Law School, 2004, Disponível em: <http://www.jura.uni-frankfurt.de/42852793/societal_constitutionalism.pdf> Acesso em: 17 jan. 2013.

TRIEPEL, Karl Heinrich, As relações entre o direito interno e o direito internacional, trad. port. de A. de Castro, in Revista da Faculdade de Direito da Universidade Federal de Minas Gerais, 1964.

União Europeia (UE), Parlamento Europeu, Comissão dos Assuntos Externos, SubCOMISSÃo DOS DIREITOS HUMANOS, Prêmio Sakharov para liberdade de consciência 2009, Disponível em < http://www.europarl.europa.eu/document/activities/cont/200909/20090928ATT61377/200 90928ATT61377EN.pdf >. Acesso em: 09 jan. 2013.

WEIS, Celso, Direitos humanos contemporâneos, São Paulo, Malheiros, 1999.

ZAGREBELSKy, Gustavo, El derecho dúctil - ley, derechos, justicia, trad. esp. de Maria Gascón, $7^{\mathrm{a}}$ ed., Madri, Trotta, 2007.

ZISMAn, Célia Rosenthal, A liberdade de expressão na Constituição Federal e suas limitações - os limites dos limites, São Paulo, Paulista, 2003.

\section{FONTES PRIMÁRIAS}

BRASIL, Supremo Tribunal Federal, Medida Cautelar em Arguição de Descumprimento de Preceito Fundamental, Autor: Partido Democrático Trabalhista - PDT. Relator: Ministro Relator Carlos Ayres Britto, Julgamento: 30 abr. 2009, Disponível em < http://redir.stf.jus.br/paginadorpub/paginador.jsp?docTP=AC\&docID=605411 > $\quad$ Acesso em: 20 jan. 2013>.

ESTADOS UNIDOS DA AMÉRICA, The United States District Court for the Eastern District of Pennsylvania, Civil Action n. ${ }^{\circ}$ 96-963, Julgamento: 11 jun. 1996, Disponível em: 〈http://www.law.duke.edu/boylesite/aclureno.htm> Acesso em: 09 jan. 2013. 
ESTADOS UNIDOS DA AMÉRICA, The United States District Court for the Eastern District of Pennsylvania, Civil Action n. ${ }^{\circ}$ 96-1458, Julgamento: 11 jun. 1996, Disponível em: <http://www.law.duke.edu/boylesite/aclureno.htm> Acesso em: 09 jan. 2013.

\section{SITES DE INTERNET:}

Após protestos de sites, leis antipiratarias perdem apoio nos EUA, in Globo.com, 08/01/2012, Disponível em:〈http://g1.globo.com/tecnologia/noticia/2012/01/sites-fora-doar-e-mensagens-marcam-atos-contra-lei-antipirataria-nos-eua.html >. Acesso em: 09 jan. 2013.

Egito bloqueia a internet e celular para conter megaprotestos, in Folha de São Paulo Caderno Mundo, 28/01/2011, Disponível em: $<$ http://www1.folha.uol.com.br/mundo/867206-egito-bloqueia-internet-e-celular-paraconter-megaprotestos.shtml>. Acesso em: 09 jan. 2013.

Entenda o SOPA e o PIPA, projetos de lei que motivam protestos de sites, in Globo.com, 18/01/2012, Disponível em: <http://g1.globo.com/tecnologia/noticia/2012/01/entenda-oprojeto-de-lei-dos-eua-que-motiva-protestos-de-sites.html >. Acesso em: 09. Jan. 2013.

Isto é 'Gomorra', in Folha de São Paulo - Caderno Mais!, 26/04/09, p.05, Disponível em: <http://www1.folha.uol.com.br/fsp/mais/fs2604200909.htm>. Acesso em: 09 jan. 2013.

Luta por liberdade revoluciona norte africano e península arábica, in Terra, Disponível em: <http://www.terra.com.br/noticias/infograficos/protestos-mundo-arabe/>. Acesso em: 09 jan. 2013.

Protests against SOPA and PIPA, in Wikipedia - the free encyclopedia, Disponível em: 〈http://en.wikipedia.org/wiki/Protests_against_SOPA_and_PIPA〉. Acesso em: $08 \mathrm{dez}$. 2012.

Sodoma e Gomorra, in Wikipedia - a enciclopédia livre, Disponível em: < http://pt.wikipedia.org/wiki/Sodoma_e_Gomorra>. Acesso em 09 de jan 2013.

Take action - a free and open world depends on a free and open web, Disponível em: <https://www.google.com/takeaction/>. Acesso em: 09 jan. 2013. 
Wikipedia - SOPA initiative, in Wikipedia - the free encyclopedia, Disponível em: <http://en.wikipedia.org/wiki/Wikipedia:SOPA_initiative>. Acesso em: 08 dez. 2012.

http://wikileaks.org/. Acesso em 09 jan. 2013.

http://www.terra.com.br/noticias/infograficos/protestos-mundo-arabe/. Acesso em 09 jan. 2013. 


\section{RESUMO}

A partir de uma distinção entre o aspecto interno e o aspecto externo de liberdade, reconheceu-se a necessidade de conferir proteção ao exercício da liberdade de expressão no espaço físico, em um plano exterior, portanto, ao indivíduo. Com o avento da sociedade informacional, as novas tecnologias comunicacionais alteraram as condições do discurso, de modo a refletir nas possibilidades de exercício da liberdade de expressão. A criação da Internet, bem como da tecnologia de digitalização, ao permitir que qualquer conteúdo traduzido em dígitos seja acessado por qualquer indivíduo conectado à rede mundial de computadores, a despeito de sua localização geográfica, possibilitou a formação de um espaço virtual, o qual passa a ser o âmbito por excelência do exercício da liberdade de expressão. No espaço virtual, há a liberação do polo de emissão, de modo que o indivíduo assume um papel ativo na criação de novos conteúdos, em comunhão com os demais em um ambiente em rede. 


\begin{abstract}
Starting from a distinction between the internal aspect and the external aspect of freedom, it is possible to recognize the need to provide protection to the exercise of freedom of expression in physical space, in an outer plane, therefore, from the individual. With the informational society, the new communication technologies have altered the conditions of speech, reflecting on the possibilities of freedom of expression. The creation of the Internet, as well as the digital technology, by allowing that any content translated into digits can be accessed by anyone connected to the worldwide web, regardless of their geographic location, made it possible to establish a virtual space, which becomes the ultimate scope of the exercise of freedom of expression. In the virtual space, there is the release of the emission polo, so that individuals take an active role in the creation of new content, in communion with the other in a networked environment.
\end{abstract}

